\title{
Partial Stereotactic Ablative Boost Radiotherapy in Bulky Non-Small Cell Lung Cancer: A Retrospective Study [Corrigendum]
}

\author{
Bai Y, Gao XS, Qin SB, et al. Onco Targets Ther. \\ 2018;11:2571-2579.
}

Recently the authors found two main errata in the text that need to be corrected.

On page 2571, Abstract, Results section, "Two-year overall survival was $55.6 \%$. Two-year local control rate was $85.7 \%$ " should read "One-year overall survival was $64.9 \%$. One-year local control rate was $100 \%$ ".

On page 2574, Response and survival outcomes section, 3rd and 4th sentences, "One-year over-all survival was $88.2 \%$. Two-year overall survival was 55.6\% (Figure 2A)." should read "One-year over-all survival was $64.9 \%$. Two-year overall survival was $44.5 \%$ (Figure $2 \mathrm{~A}$ )."

On page 2574, Response and survival outcomes section, 10th sentence, "Two-year local control rate was $85.7 \%$. (Figure 2B)." should read "Two-year local control rate was 57.1\%. (Figure 2B)."

On page 2575, Figure 2 legend, “(A) Kaplan-Meier plots of overall survival for all patients. One-year overall survival was $88.2 \%$. Two-year overall survival was $55.6 \%$. (B) KaplanMeier plots of local control for all patients. One-year local control rate was $100 \%$. Two-year local control rate was $85.7 \%$. (C) Patients with B90 $\geq 65 \%(\mathrm{n}=19)$ achieved a higher local control rate than those with $\mathrm{B} 90<65 \%(\mathrm{n}=11)$ (median survival $=15.2$ months vs 3.5 months, $\mathrm{CI}=6.8-23.6$ and $2.2-4.9$ months, respectively; $\mathrm{P}=0.010$ ). (D) Patients with $\mathrm{B} 80 \geq 90 \%$ $(n=20)$ achieved a higher local control rate than those with
B $80<90 \% \quad(\mathrm{n}=10)$ (median survival=14.9 months vs 3.5 months, $\mathrm{CI}=3.4-26.3$ and 1.8-5.2 months, respectively; $\mathrm{P}=0.045)$." should read "(A) Kaplan-Meier plots of overall survival for all patients. One-year overall survival was $64.9 \%$. Two-year overall survival was $44.5 \%$. (B) Kaplan-Meier plots of local control for all patients. One-year local control rate was $100 \%$. Two-year local control rate was $57.1 \%$. (C) Patients with $\mathrm{B} 90 \geq 65 \%(\mathrm{n}=19)$ achieved a higher local control rate than those with $\mathrm{B} 90<65 \%(\mathrm{n}=11)$ (median survival $=15.2$ months vs 3.5 months, $\mathrm{CI}=6.8-23.6$ and 2.2-4.9 months, respectively; $\mathrm{P}=0.010)$. (D) Patients with $\mathrm{B} 80 \geq 90 \%(\mathrm{n}=20)$ achieved a higher local control rate than those with B $80<90 \%$ $(\mathrm{n}=10)$ (median survival=14.9 months vs 3.5 months, $\mathrm{CI}=3.4-26.3$ and $1.8-5.2$ months, respectively; $\mathrm{P}=0.045)$."

On page 2576, Discussion section, last sentence "Therefore, daily SABR was applied in our article and the 2-year local control rate was as high as $85.7 \%$, even stage IV NSCLC were $40 \%$." should read "Therefore, daily SABR was applied in our article and the 1-year local control rate was as high as $100 \%$, even stage IV NSCLC were $40 \%$."

Despite the correction in the text list as above, the Figures of Kaplan-Meier plots of overall survival and local control are correct, and the error doesn't the change the overall findings reported in the paper. We can still conclude that "This retrospective study suggests that P-SABR is feasible and well tolerated in bulky NSCLC. Local control rate is encouraging, especially for the $\mathrm{B} 90 \geq 65 \%$ group, which may due to the ability of P-SABR to optimize BED with equivalent toxicity". The authors apologize for this error.

\section{Dovepress}

\section{Publish your work in this journal}

OncoTargets and Therapy is an international, peer-reviewed, open access journal focusing on the pathological basis of all cancers, potential targets for therapy and treatment protocols employed to improve the management of cancer patients. The journal also focuses on the impact of management programs and new therapeutic

agents and protocols on patient perspectives such as quality of life, adherence and satisfaction. The manuscript management system is completely online and includes a very quick and fair peer-review system, which is all easy to use. Visit http://www.dovepress.com/ testimonials.php to read real quotes from published authors. 